\title{
Systematics, fishery and biology of the white sardine Escualosa thoracata (Valenciennes, 1847) exploited off Kerala, south-west coast of India
}

\author{
E. M. ABDUSSAMAD, K. G. MINI, R. GIREESH, D. PRAKASAN, T. B. RETHEESH, \\ PRATHIBA ROHIT AND A. GOPALAKRISHNAN \\ ICAR-Central Marine Fisheries Research Institute, Ernakulam North P. O., Kochi - 682018 , Kerala, India \\ e-mail: emasamadg@gmail.com
}

\begin{abstract}
Landings of the white sardine Escualosa thoracata (Valenciennes, 1847) indicated a shift in their abundance from northeast to south-west coast of India and a sharp decline in the resource landings during the last decade along the entire range of its distribution. High local demand coupled with competitive price for the species might have led to overexploitation of this otherwise seasonal resources along the major areas of its abundance along the Indian coast. Detailed study on the systematics, fishery and biology of the species landed along Kerala coast was undertaken during 2015 and 2016. Stock assessment studies indicated near optimum fishing pressure on the resource along the Kerala coast.
\end{abstract}

Keywords: Abundance, Escualosa thoracata, Growth, Maturity, White sardine

\section{Introduction}

White sardines are small pelagic fishes of the genus Escualosa under the family Clupeidae. Globally only two valid species viz., the slender white sardine Escualosa elongata Wongratana, 1983 and the white sardine Escualosa thoracata (Valenciennes, 1847) (Fig. 1) have been documented. Distribution of the slender white sardine is restricted to the Gulf of Thailand in the western Pacific. The white sardine E. thoracata enjoys a wide distribution along Indo-West Pacific region along the coasts of Pakistan, India, Thailand, Indonesia, Philippines, Papua New Guinea and Australia. White sardine supports a seasonal fishery in the areas of their distribution along the Indian coast. They are considered a delicacy especially among coastal community and fetch fairly high unit price. Though the species supports an important fishery in India, information on their biology and population dynamics are limited. Some information on fishery and biology of the species is available from Devanesan and John (1941), Chidambaram and Venkataraman (1946), Devanesan and Chidambaran (1948), Mookerjee and Bhattacharya (1950), Nair (1951; 1972), Dutt (1971), Dutt and Rao (1981), Shivaprakasha and Joseph (1988), Raje et al. (1994), Shabir et al. (2014) and Sikha et al. (2016). The present study was carried out to update the systematics and biological information on the species and to evaluate the present state of the stock along Kerala coast.

\section{Materials and methods}

Fishery and biology of the white sardine E. thoracata along the Kerala coast were monitored during 2015 and
2016. State-wise landings data of the species collected from catch statistics of the ICAR-Central Marine Fisheries Research Institute (ICAR-CMFRI), Kochi for the period 2007-2015 was used for catch trend analysis.

Length frequency data of the species in the catch was collected following standard random sampling procedure. The length-weight relationship was calculated as per Le Cren (1951). Growth parameters were estimated using the ELEFAN I module of FiSAT software and the Powell-Wetherall plot (Gayanilo et al., 1996) and other relevant growth parameters as per Pauly (1979; 1983a; 1984) as well as Pauly and Munro (1984). Mortality and exploitation rates were estimated following Pauly (1980;1983b).

\section{Results and discussion}

Systematics

$\begin{array}{ll}\text { Valid name } & : \text { Escualosa thoracata } \\ \text { Class } & : \text { Actinopterygii } \\ \text { Order } & : \text { Perciformes } \\ \text { Suborder } & : \text { Scombroidei } \\ \text { Family } & : \text { Clupeidae } \\ \text { Subfamily } & : \text { Dorosomatinae } \\ \text { Genus } & : \text { Escualosa } \\ \text { Species } & : \text { thoracata (Valenciennes, 1847) } \\ \text { Common name } & \text { : White sardine }\end{array}$

Distinguishing characters

Body fusiform, moderately deep and compressed with strongly keeled belly, mouth superior, dorsal profile of head more or less straight, second supra-maxilla almost 


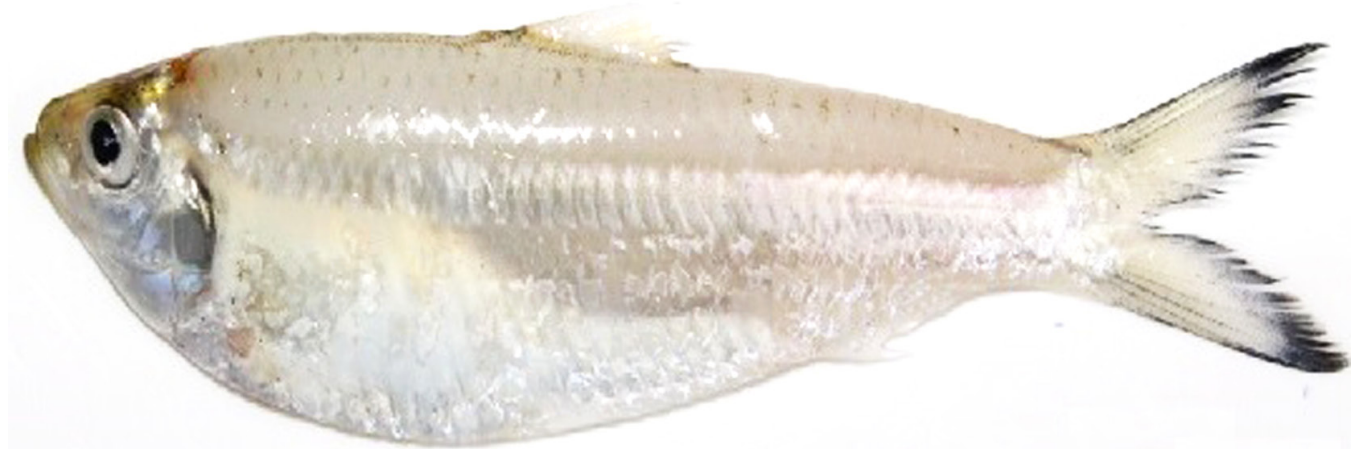

Fig. 1. Esculosa thoracata (Valenciennes, 1847)

rectangular. Broad bright silver stripe present along the flank. Distinguished from Escualosa elongata by its deeper body and presence of broad silver stripe along the flank. Fin formulae: Dorsal spines (total): 0; Dorsal soft rays (total): 13 - 21; Anal spines: 0; Anal soft rays: 14-19.

\section{Fishery}

White sardine fishery is supported by a single species, E. thoracata along the coast. They generally form shoals in shallow waters of 5 to $30 \mathrm{~m}$ depth zone, preferably close to shore and are caught with encircling nets, particularly ring seines. Small quantity are also caught by gillnets, dolnets and trawls. Motorised and nonmechanised crafts are engaged in the fishery. Shoals of juveniles often enter backwaters and form minor fishery in drag nets, stake nets and cast nets. Along Kerala coast, about $67 \%$ of the catch was by ring seines during 2015-16 (Fig. 2). Gillnet contribution was 21\%, trawl $4.4 \%$ and other traditional gears contributed $7.5 \%$. Fishing operation is done by small outboard units in shallow waters.

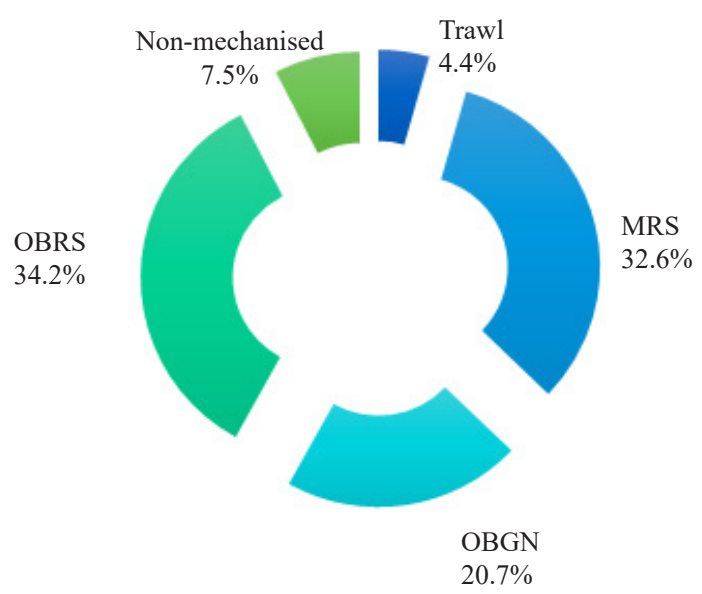

Fig. 2. Major gears contributing to the landings of Escualosa thoracata in Kerala during 2015-16
Fishery along the Indian coast exhibited wide annual fluctuation with an average landing of 13,885 $\mathrm{t}$ during 2007-12 (Fig. 3). Landings registered a downward trend thereafter with the lowest landings in 2015. Fishery along the Kerala coast improved over the years to a peak of $5044 \mathrm{t}$ in 2014. It dropped steeply to $1689 \mathrm{t}$ in 2015 , but increased to an all time high of $5484 \mathrm{t}$ in 2016.

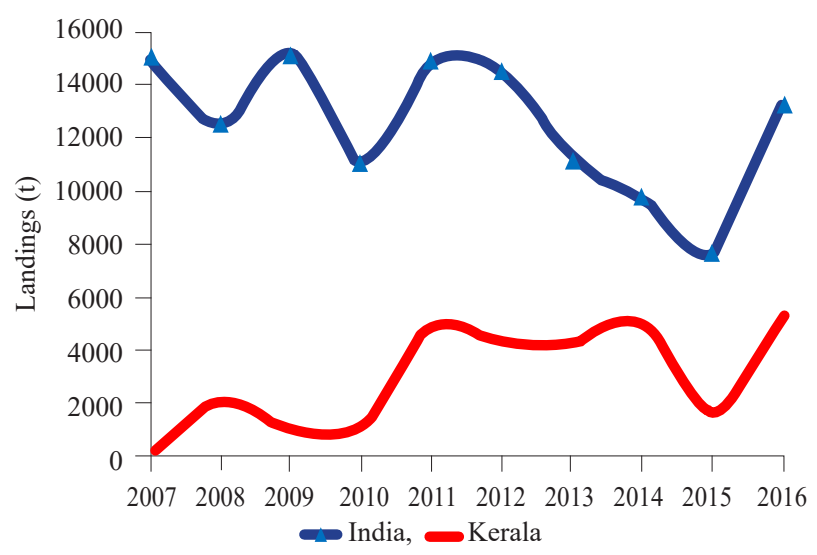

Fig. 3. Trend in the white sardine landings along the Indian coast (2007-2016)

Major contributors to the fishery were Andhra Pradesh, West Bengal and Odisha till 2010 (Fig. 4). Thereafter, fishery along the east coast declined. Kerala, Karnataka and Maharashtra are the major contributors to the white sardine fishery in the recent years.

Size composition in the catch

Catch along the Kerala coast was supported by 36 to $102 \mathrm{~mm}$ fishes with $60-90 \mathrm{~mm}$ group as the mainstay of the fishery during 2015-16 (Table 1). Reports by earlier workers indicate the fishery was supported by almost similar size groups all along the coast (Devanesan and John, 1941; Chidambaram and Venkataraman, 1946; Devanesan and Chidambaran, 1948; Raje, et al., 1994; 


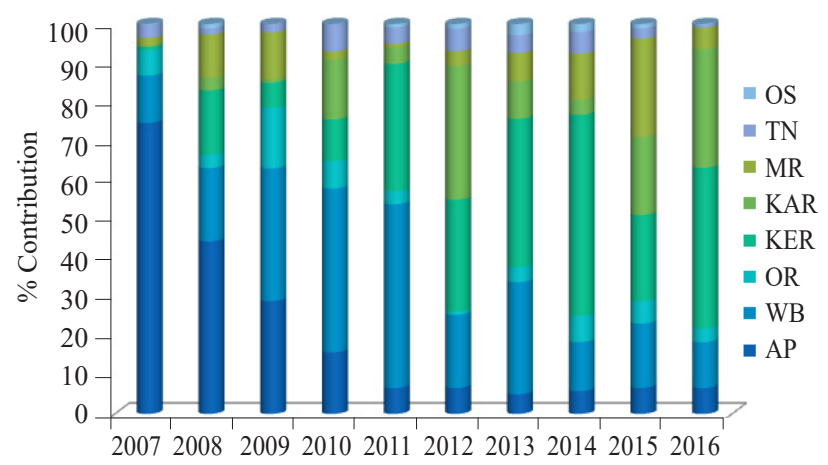

Fig. 4. State-wise contribution of white sardine during 2007-16 OR-Odisha TN-Tamil Nadu, MR-Maharashtra, KAR-Karnataka, KER-Kerala, WB-West Bengal, AP-Andhra Pradesh, OS-Other states

Table 1. Size range of white sardine in Indian waters

\begin{tabular}{lll}
\hline Size range $(\mathrm{mm})$ & Area & Author \\
\hline $25-72$ & Mumbai & Mookerji and Bhattacharya (1950) \\
$100-110$ & Malabar coast & Nair (1951) \\
$41-105$ & Mumbai & Raje et al. $(1994)$ \\
$4.9-10.9$ & Mumbai & Shabir et al. $(2014)$ \\
$22-111$ & Mumbai & Sikha et al. (2016) \\
$36-102$ & Kerala & Present study (2015-16) \\
\hline
\end{tabular}

Shabir et al., 2014; Shikha et al., 2016). Further, the growth estimate indicated that almost $95-98 \%$ of the fishes caught belong to zero year class. Further, the length data shows that fishery at all areas were supported by unimodal population. Nair (1951) also reported only one age group in the fishery, indicating that the species spawns only once in a year and the stock behaves as an annual crop.

\section{Length-weight relationship}

Length-weight relationship was estimated for the unsexed population $(\mathrm{n}=293)$ as: $\mathrm{W}=0.00459132 \mathrm{~L}^{3.295218}$ (Fig. 5). The relationship is also available from the works of Raje et al. (1994) and Shabir et al. (2014). Raje et al. (1994) estimated the relationship separately for both sexes as:

$$
\begin{aligned}
& \text { Males }: \mathrm{W}=0.000001508 \mathrm{~L}^{3.3946} \\
& \text { Females }: \mathrm{W}=0.000002561 \mathrm{~L}^{3.2706}
\end{aligned}
$$

For unsexed population, the relationship was derived as: $\mathrm{W}=0.0048 \mathrm{~L}^{3.2367}$ by Shabir et al. (2014). These estimates indicate that growth of the species is allometric.

\section{Biology}

Food and feeding: Food was dominated by planktonic forms, which included copepods, cladocerans and post-larval forms of shrimps and fishes. Crustaceans constituted a major component of the gut during most months. Phytoplankton were also observed occasionally in the guts in small numbers. Raje et al. (1994) reported

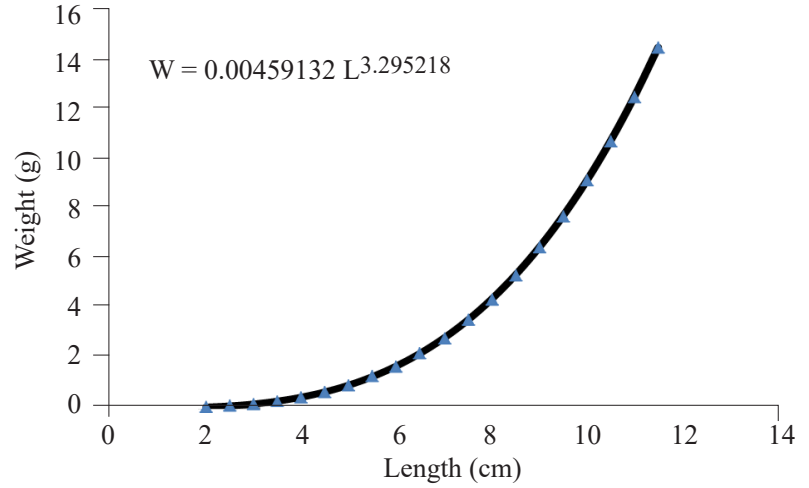

Fig. 5. Length-weight curve of white sardine from Kerala coast

that the species in Mumbai waters feed on copepods, cladocerans, eggs as well as larval forms of fishes, molluscs and crustaceans. It has also been reported that intensive feeding takes place during post-monsoon months, when there is rich production of plankton.

\section{Reproductive biology}

Sex ratio: The white sardine population is mostly female dominated along the Kerala coast (Table 2). The M: F ratio of the species during the period was $0.93: 1$. Reports from Mumbai waters also indicate predominance of females in the population with an annual sex-ratio of 0.83:1 (Raje et al., 1994).

Sexual maturity: The species attain sexual maturity in the sea along shallow coastal waters. Full sexual maturity was observed from $66 \mathrm{~mm}$ size onwards in both males and females. In females, $50 \%$ maturity was observed at $80 \mathrm{~mm}$ size and in males at $78 \mathrm{~mm}$. Information on gonadal maturity of the species is also available from the works of Chidambaram and Venkataraman (1946) and Raje et al.

\begin{tabular}{|c|c|c|c|}
\hline Month & Male & Female & Male: Female \\
\hline \multicolumn{4}{|c|}{ Mumbai coast (Raje et al., 1994) } \\
\hline January & 55 & 82 & $0.67: 1$ \\
\hline February & 67 & 72 & $0.93: 1$ \\
\hline March & 57 & 69 & $0.82: 1$ \\
\hline April & 109 & 112 & $0.97: 1$ \\
\hline May & 75 & 88 & $0.85: 1$ \\
\hline June & 52 & 50 & $1.04: 1$ \\
\hline July & 65 & 90 & $0.72: 1$ \\
\hline August & 6 & 9 & $0.67: 1$ \\
\hline September & - & - & - \\
\hline October & 24 & 40 & $0.60: 1$ \\
\hline November & 10 & 14 & $0.71: 1$ \\
\hline December & 47 & 57 & $0.82: 1$ \\
\hline Pooled & 567 & 683 & $0.83: 1$ \\
\hline \multicolumn{4}{|c|}{ Kerala (2015-‘16) } \\
\hline Present study & 185 & 199 & 0.93:1 \\
\hline
\end{tabular}

Table 2. Sex ratio of white sardine population 
(1994); and on spawning from the reports of Devanesan and John (1941). Chidambaram and Venkataraman (1946) observed maturity in females from $64 \mathrm{~mm}$ size onwards and $50 \%$ of the females matured at $82 \mathrm{~mm}$ in Mumbai waters. Raje et al. (1994) reported it as $80 \mathrm{~mm}$ from the same area.

Spawning: Maturity studies indicated that they spawn along the Kerala coast during October-February with peak spawning activity during December-January. Fishes with well developed ovaries were observed in the population by early October and fishes with spent ovaries by the end of October. Presence of large proportion of fishes with spent gonads during December-January in the catch indicated this as the peak spawning period.

Spawning season of the species was described by Devanesan and John (1941) as well as Nair (1951) based on the changes in the gonadal condition and occurrence of eggs in the plankton. They confirmed that spawning season of the species along the west coast of India was from November-February with peak activity during January-February. They observed spawning females, with transparent eggs having clear oil globules since November, and fishes with spent and recovering gonads since December with large proportion in January and February.

Fecundity: Fecundity of the species caught along the Kerala coast varied between 6,500 and 8,940 depending on the size of the female (78-99 mm). Nair (1951) estimated their fecundity as 8000 per fish. According to him, left lobe of testis and ovary alone are functional and there is complete atrophy in right gonads in the species which partly accounts for their low fecundity.

\section{Stock status}

Growth and longevity: Growth of the species along Kerala coast was estimated following modal progression analysis. The species is found to grow to a maximum size of $105 \mathrm{~mm}$ (Fig. 6). They grow to 50, 79, 96 and $106 \mathrm{~mm}$ in 3, 6, 9 and 12 months respectively. Longevity was estimated as one year and the von Bertalanffy growth equation was fitted as:

$$
\mathrm{Lt}=11.87\left[1-\mathrm{e}^{-2.192(\mathrm{t}+0.00261)}\right]
$$

Information on growth of the species in Mumbai waters is available from the works of Devaraj (1983); Raje et al. (1994) and Shikha et al. (2016) (Table 3 and 4). Growth is relatively slow and the fish reaches 65.3 to $72.2 \mathrm{~mm}$ in six months and 91.8 to $100.8 \mathrm{~mm}$ in one year. Mookerjee and Bhattacharya (1950), estimated a growth of $49.5 \mathrm{~mm}$ in 6 months from an initial size of

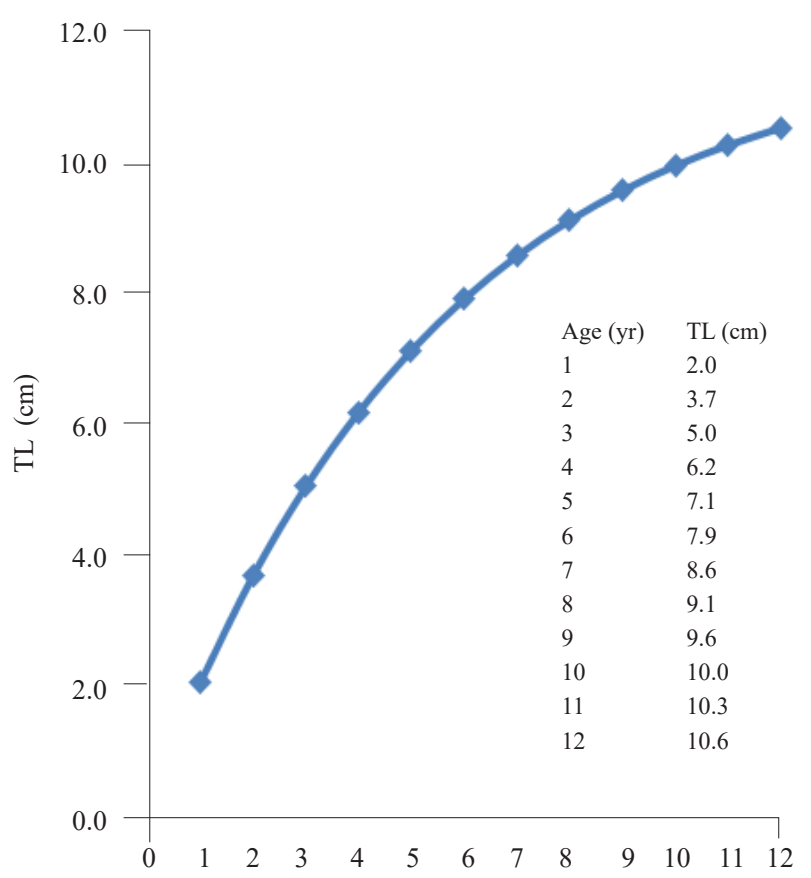

Fig. 6. Growth curve of white sardine (Kerala coast)

Table 3. Growth estimates in $\mathrm{mm}$ for white sardine in Indian waters

\begin{tabular}{llll}
\hline 6 months & 1 year & Area & Author \\
\hline 49.5 & - & - & $\begin{array}{l}\text { Mookerjee and } \\
\text { Bhattacharya (1950) }\end{array}$ \\
65.3 & 91.8 & Mumbai & Raje et al. (1994) \\
72.17 & 100.79 & Mumbai & Sikha et al. (2016) \\
79.0 & 106 & Kerala & Present study (2015-16) \\
\hline
\end{tabular}

Table 4. Estimates of growth parameters of white sardine in Indian waters

\begin{tabular}{lllll}
\hline $\mathrm{L}_{\infty}(\mathrm{mm})$ & $\mathrm{K}\left(\right.$ year $\left.^{-1}\right)$ & $\mathrm{t}_{\mathrm{o}}$ (year) & Area & Author \\
\hline 110 & 1.8 & - & Mumbai & Raje et al. $(1994)$ \\
118.81 & 1.85 & 0.000095 & Mumbai & Sikha et al. $(2016)$ \\
11.87 & 2.192 & -0.00261 & Kerala & Present study (2015-16) \\
\hline
\end{tabular}

$25.5 \mathrm{~mm}$ to $75 \mathrm{~mm}$. Their life span in Mumbai waters was estimated as 1.7-1.8 years. Nair (1951) inferred the average life span of the species as one year, with only a small proportion surviving beyond one year. Estimates of growth parameters, $\mathrm{L}_{\infty}, \mathrm{K}$ and $\mathrm{t}_{\mathrm{o}}$ ranged between 110 and $121 \mathrm{~mm} ; 1.8$ and 1.85 per year and 0.000095 and -0.00261 year respectively.

Mortality and exploitation rates: Natural mortality (M) of the species was estimated as 2.43 and fishing mortality (F) as 6.22 (Table 5). Fishing mortality is more than 2.5 times of natural mortality, indicating fairly high fishing pressure on the resource. The exploitation rate $\left(\mathrm{E}_{\text {curr }}\right)$ was 0.72 which is same as $\mathrm{E}_{\mathrm{opt}}$, but lower than the $\mathrm{E}_{\max }$. This 
Table 5. Biological reference points estimated for white sardine along Kerala coast

\begin{tabular}{llllll}
\hline $\begin{array}{l}\mathrm{L}_{\mathrm{r}} \\
(\mathrm{mm})\end{array}$ & $\begin{array}{l}\mathrm{L}_{\max } \\
(\mathrm{mm})\end{array}$ & $\begin{array}{l}\text { Mean } \\
(\mathrm{mm})\end{array}$ & $\begin{array}{l}\text { Modes } \\
(\mathrm{mm})\end{array}$ & $\begin{array}{l}\mathrm{L}_{\mathrm{m}} \\
(\mathrm{mm})\end{array}$ & $\begin{array}{l}\mathrm{L}_{\mathrm{c}} \\
(\mathrm{mm})\end{array}$ \\
36 & 102 & 74.5 & $55-60$, & 80 & 54.2 \\
\hline $\mathrm{M}$ & $\mathrm{F}$ & $\mathrm{E}_{\text {curr }}$ & $\mathrm{E}_{\text {opt }}$ & $\mathrm{E}_{\max }$ & $\mathrm{SSB} \%$ \\
2.43 & 6.28 & 0.72 & 0.72 & 0.78 & 38 \\
\hline
\end{tabular}

indicated that the resource is exploited at optimum levels along the Kerala coast.

Estimates of mortalities and exploitation rates for Mumbai coast is available from Shika et al. (2016) as: $\mathrm{M}=2.79$ year $^{-1}, \mathrm{~F}=4.35$ year $^{-1}$ and total mortality $(\mathrm{Z})=7.14$ year $^{-1}$. The $\mathrm{M} / \mathrm{K}$ and $\mathrm{Z} / \mathrm{K}$ values were calculated as 1.86 and 4.22 , while exploitation rate and exploitation ratio estimated were 0.556 year $^{-1}$ and 0.557 year $^{-1}$ respectively.

The biological reference points estimated for the species indicated that, the resource is exploited at optimum level along the Kerala coast. The spawning stock biomass was also found to be at fairly high level.

White sardines form only a seasonal fishery throughout their range of distribution along the Indian coast. However, they enjoy considerable local demand irrespective of the abundance of other fishes in the catch. Though the resource did not form a major fishery during earlier days, owing to the domestic preference as a delicacy, the species enjoyed considerable economic importance in the traditional fishery. Despite their domestic demand, they never received much attention from researchers and policy makers due to highly seasonal nature of the fishery, low abundance and production. Fishers however target the resource whenever available, irrespective of the abundance of other resources, owing to local demand and high price. Fluctuations in their fishery, as observed in the present study from the Kerala coast is due to fluctuation in their abundance. Being the natural resident of heavily fished shallow coastal waters, both targeted and non-targeted fishing pressure are always high on the stock, which might have contributed heavily to the declined catch levels from fishing grounds along other parts of the Indian coast. Being coastal in distribution and spawning restricted to shallow waters, spawn survival depend heavily on the coastal environment, competitors and predators. This also might have added to the decline in the fishery along the previously rich fishing grounds. There is dearth of information on the biology and population characteristics of this species, and hence there is need for detailed investigations in order to have proper understanding about the fluctuations in the fishery of the species.

\section{References}

Chidambaram, K. and Venkataraman, R. S. 1946. Tabular statements on the natural history of certain marine food fishes of the Madras Presidency. West Coast Gout Press, Madras, p. 1-26.

Devanesan, D. V. and Chidambaram, K. 1948. The common food fishes of the Madras Presidency. Government Press, Madras, $79 \mathrm{pp}$.

Devanesan, D. V. and John, V. 1941. On the natural history of Kowala thoracata Cuv. \& Val., with special reference to its gonads and eggs. Rec. Ind. Mus., 43: 215-216.

Devaraj, M. 1983. Fish populayion dynamics : A course manual. Central Institute of Fisheries Education, Mumbai, p. 83-89.

Dutt, S. 1971. On 'Kowala thoracata' Cuvier and Valenciennes of Cantor (1950). J. Mar. Biol. Ass. India, 13(1\&2): 145-146.

Dutt, S. and Rao, B. V. S. 1981. Biometric comparison of samples of the clupeid fish, Esculosa thoracata (Val., 1847) from two localities. Matsya, 7: 50-63.

Gayanilo, F. C. Jr., Sparre, P. and Pauly, D. 1996. The FAOICLARM Stock Assessment Tools (FiSAT) User's Guide. FAO computerized information series (Fisheries). No. 8. FAO, Rome, 126 pp.

Le Cren, E. D. 1951. The length-weight relationship and seasonal cycle in gonad weight and condition in the perch (Perca fluviatilis). J. Anim. Ecol., 20: 201-219.

Mookerjee, H. K. and Bhattacharya, R. 1950. Some aspects of the natural history of Clupea lile. Proceedings of the $37^{\text {th }}$ Indian Science Congress, p. 250-251.

Nair, R. V. 1951. Studies on the life history, bionomic and fishery of the white sardine, Kowala coval (Cuv.). Proceedings of the third meeting of the Indo-Pacific Fisheries Council, Madras, p. 103-111.

Nair, R. V. 1972. Indian sardines. CSIR Zoological Monograph No. 2. Publication and Information Directorate, Central for Scientific and Industrial Research, New Delhi.

Pauly, D. 1979. Theory and management of tropical multi-species stocks. A review with emphasis on the South-east Asian demersal fisheries. ICLARM Stud. Rev., 1: $35 \mathrm{pp}$.

Pauly, D. 1980. On the interrelationships between natural mortality, growth parameters and mean environmental temperature in 175 fish stocks. L. Cons. Ciem., 39(2): 175-192.

Pauly, D. 1983a. Some simple methods for the assessment of tropical fish stocks. FAO Fisheries Technical Paper, 243: $52 \mathrm{pp}$. 
Pauly, D. 1983b. Length converted catch curves. A powerful tool for fisheries research in tropics (Part-1). ICLARM Fishbyte, 1(2): 9-13.

Pauly, D. 1984. Length converted catch curves. A powerful tool for fisheries research in tropics (Part-II). ICLARM Fishbyte, 2(1): 13-14.

Pauly, D. and Munro, J. L. 1984. Once more, on the composition of growth in fish and invertebrates. Fishbyte, 2(1): 21.

Raje, S. G., Deshmukh, V. D. and Das, T. 1994. Fishery and biology of white sardine, Escualosa thoracata (Valenciennes) at Versova, Bombay. J. Indian Fish. Ass., 24: 51-62.
Shabir, A. D., Thomas, S. N., Chakraborty, S. K. and Jaiswar, A. K. 2014. Length-weight relationships for five species of Clupeidae caught from Mumbai coast. Fish. Technol., 51: 291-294.

Shikha, R., Chakraborty, S. K., Jaiswar, A. K., Shenoy, L. and Raje, S. G. 2016. Preliminary study on growth and mortality of Escualosa thoracata (Valenciennes, 1847) from Mumbai waters. Indian J. Geo-Mar. Sci., 45(2): 290-295.

Shivaprakasha, S. M. and Joseph, S. P. 1988. Reproductive biology of the white sardine Kowala coval (Cuvier) from the Mangalore coast. Proceedings.of the First Indian Fisheries Forum, 4 - 8 December, 1987, Mangalore, India, $221 \mathrm{pp}$. 